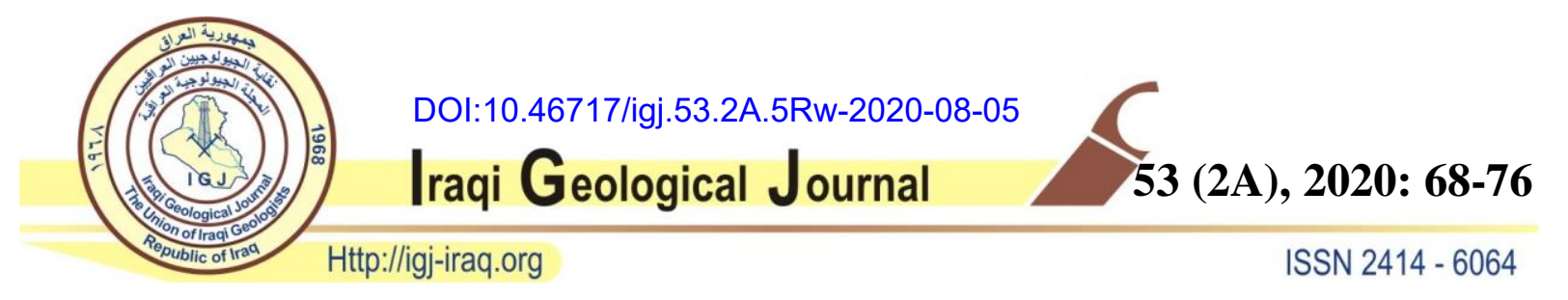

\title{
DIFFERENTIAL ENTRAPMENT OF CHARGED HYDROCARBON IN ALAN FIELD, NORTHERN IRAQ
}

\author{
${ }^{1}$ Nasser H. O. Alhadithi and ${ }^{2}$ Abdulkhaleq A. Alhadithi* \\ ${ }^{1}$ North Oil Company, Iraq \\ ${ }^{2}$ Department of Applied Geology, College of Science, University Of Anbar, Ramadi, Iraq \\ "E-mail: abdul.6363@uoanbar.edu.iq \\ Received: 20 April 2020; accepted: 3 June 2020
}

\begin{abstract}
The Alan oilfield consists of three domes western, middle and eastern. Well Alan-1 and Well Alan-2 are drilled in the middle and western domes respectively. Oil fills the lower part of the Kurra Chine Formation (Late Triassic) in the middle dome while it occupies the upper part of the formation from the western dome; also, the gas and condensate fill the lower part of the formation in the western dome. Alan field consists of the lower and upper reservoirs of the Kurra Chine Formation separate by $220 \mathrm{~m}$ of anhydrite cap rocks. Alan structure develops at the end of Pliocene at the northwest ridge of the Mosul High. Source rocks of Triassic sequence, especially northwest Iraq, are matured and generate hydrocarbon that migrates laterally up-dip toward Alan structure. The folding plays an important role to trap the hydrocarbon in the lower reservoir. Western dome fills by gas and condensate completely until gas-oil contact reaches to the spill point between the western and middle domes. The oil is pushed toward the middle dome because it beyond and higher than the western dome. Another factor affected the hydrocarbon distribution in the lower reservoir was the erosion of about $800 \mathrm{~m}$ from overburden of Miocene sequence upward which was led to increase the void volume of porosity for the reservoir carbonate rocks. This increase allows to release of gas and push the oil to the middle dome. Two scenarios of hydrocarbon entrapment in the lower reservoir, the first one depends on the concepts of Gussow's fill and spill, in which the source rock enters maturity levels after or within the formation of the structure. The second scenario is in which the development of structure after charge of hydrocarbons. The latter is the most widely accepted in the Alan field case.
\end{abstract} Keywords: Structural setting; Charged hydrocarbon; Kurra Chine Formation; Iraq

\section{INTRODUCTION}

Alan Oilfield locates $30 \mathrm{~km}$ northwest of the Mosul city. It is asymmetrical anticline structure in the northern part of Iraq between the latitude of N36 $26^{\prime}-\mathrm{N} 36^{\circ} 30^{\prime}$ and longitude of 
$\mathrm{E} 42^{\circ} 39^{\prime}-\mathrm{E} 42^{\circ} 58^{\prime}$. The length of its E-W, trending axis is about $28 \mathrm{~km}$ and the width is about $5 \mathrm{~km}$ (Fig. 1). It reaches to a high of $400 \mathrm{~m}$ above sea level. The average dip of the northern flank is $8^{\circ}$ while the southern flank reaches to $30^{\circ}$ nevertheless; structural map of the Kurra Chine reflector reveals that the northern flank is steeper than the southern (N. O. C., 2015).

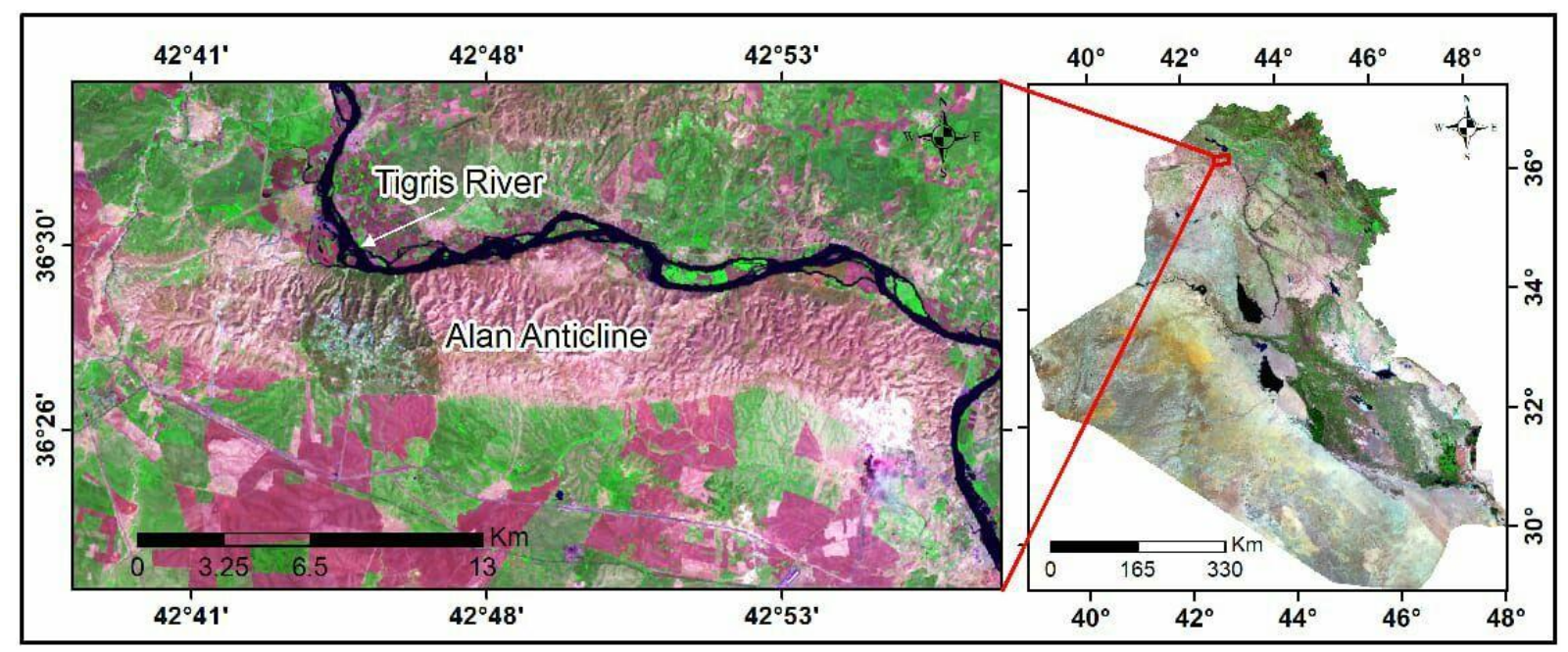

Fig. 1. Location map of Alan Anticline (Landsat 8 Satellite image RGB 642)

Alan anticline consists of three domes western, middle and eastern with small saddles between them. Middle dome is higher than the western dome about $100 \mathrm{~m}$ but it is lower than the eastern dome about 25 m (O.E.C., 2010). The well Alan 1 was drilled on the middle dome, in which the lower part of the Kurra china Formation reserves crude oil. The well Alan 2 at the western dome reserves at the upper part crude oil, in which oil water contact is at depth $-2150 \mathrm{~m}$, while gas and condensate in the lower part of the formation. Gas water contact in the western dome is at depth $-2528 \mathrm{~m}$ and lower than oil water contact in the middle dome about $47 \mathrm{~m}$. The distance between both wells is $7 \mathrm{~km}$. Well Alan-2 did not penetrate lower contact of the Kurra Chine Formation but well Alan-1was penetrated the lower contact of the Kurra china Formation (O.E.C., 2010).

The Kurra Chine Formation consists of an alternation of limestone or dolomite, shale and anhydrite sometime halite (Sadooni, 1995 and Aqrawi et al., 2010). Shale and dolomite intervals of the Kurra Chine Formation are source rocks in northern Iraq which contain fair to good total organic carbon (TOC) that belongs to type II and III kerogen (Al-Ameri et al., 2009 and Edilbi, et al., 2019). Some studies have been carried out on Alan field (O.E.C., 2009 and 2010, N.O.C., 2015) but no one was going into a convincing interpretation of why this hydrocarbon entrapment is irregular. Three aims of this paper, the first one is to interpret a rapid change in hydrocarbon - water contact between closely spaced wells Alan-1 and Alan-2, the second aim is why the lighter hydrocarbon, the gas, in the western dome is in the lower 
part of the Kurra Chine Formation whereas the oil at the upper part of the formation in the same dome. The last aim is horizontally, why the gas is accumulated in the lower part of the Kurra Chine Formation of the western dome while the oil is accumulated in the middle dome.

\section{GEOLOGICAL SETTING}

The stratigraphic sequence of Triassic Period in the northwest of Iraq is represented by the Mirga Mir Formation (Early Triassic), the Beduh Formation (Early Triassic), the Geli Khana Formation (Middle Triassic) and the Kurra Chine Formation (Late Triassic) (Buday, 1980 and Jassim et al., 1984). The Mirga Mir Formation consists of thin bedded grey and yellow argillaceous limestone and shale (Bellen et al., 1959). The thickness of the formation is $165 \mathrm{~m}$ in the north of Iraq (Jassim and Goff, 2006). The Beduh Formation comprises shale and marl with thin limestone interbeds with sandstone (Bellen et al., 1959). The Geli Khana Formation consists of dark, massive dolomites overlying thick layers of limestone in the upper division while the lower division comprises yellowish, greyish and bluish shale with thin bedded limestone (Hall, 1958). Source rocks have not been recorded in the Geli Khana Formation (Aqrawi et al., 2010). The Kurra Chine Formation consists of dark brown and black limestone and papery shale with recrystallization breccia (Bellen, et al., 1959). Some salt layers are in the middle of the formation (Jassim and Goff, 2006). Massive evaporate at the upper part of the Kurra Chine Formation seals the Triassic reservoirs (Aqrawi et al., 2010) (Fig. 2).

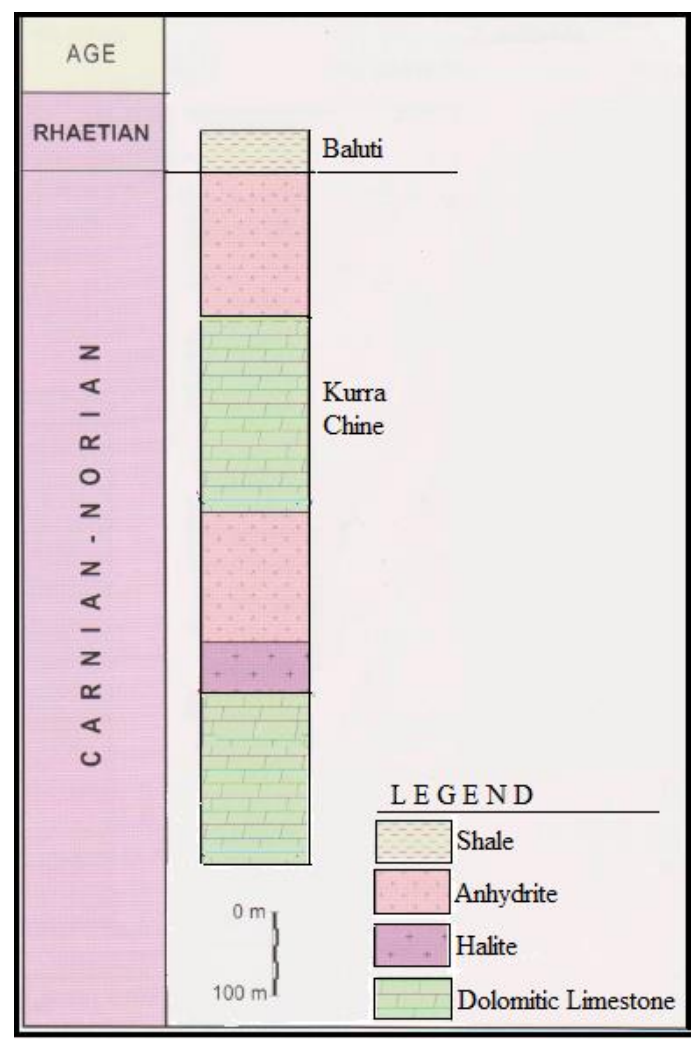

Fig. 2. Stratigraphy of the Kurra Chine (Aqrawi et al., 2010) 
Tectonically, Alan Field within the low folded zone of the Western Zagros Fold-Thrust Belt of Iraqi territory (Fouad, 2015). The field locates in the Foothill Zone within the unstable shelf (Jassim and Goff, 2006). Foothill zone contains four transversal basement blocks with different structural histories. Mosul High, where Alan field locates, is one of these four blocks. The basement is at depth $6 \mathrm{~km}$ (CGG, 1974). Compressional stress due to collision between Arabian and Eurasian plates develops many folds in the north and northwest of Iraq at end of Pliocene (Numan, 1997, Numan and Al- Azzawi, 2002 and Jassim, 2019).

\section{MATERIALS AND METHODS}

The geological cross section parallel to hinge line of the Alan anticline is done by using data of wells Alan-1 and Alan-2, and Kurra Chine reflector in some seismic sections (Fig. 3). Well data of northeast Iraq such as Alan-1 (Al-1), Alan-2 (Al-2), Atshan-1 (At-1), Qalian-1 (Q1-1), Ibrahim-1 (Ib-1), Adaiyh-1 (Ad-1), Mityaha-1 (Mt-1), Tel Hajar-1 (Th-1), Ain Ghazal-1 (Ag-1), Abtakh-1 (Ab-1), Sufaiyah-1 (Sf-1), Ain Zalah-29 (Az-29), Rafan-1 (Ra-1), Butmah-15 (Bt-15), Kand-1 (Qd-1) and Sasan-2 (Sa-2) are used to draw synoptic block diagram to the upper surface of the Kurra Chine Formation by using Surfer 16 software (Fig . 4). The figure shows Alan Field locates at northwest margin of Mosul High. Kurra Chine Formation in the Alan Field is higher than it in west and northwest area where well Abtakh-1 is located about $1200 \mathrm{~m}$. It's important to refer to the thickness variations in the sequence of the upper Triassic and Lower Jurassic formations within the studied area (Table 1).

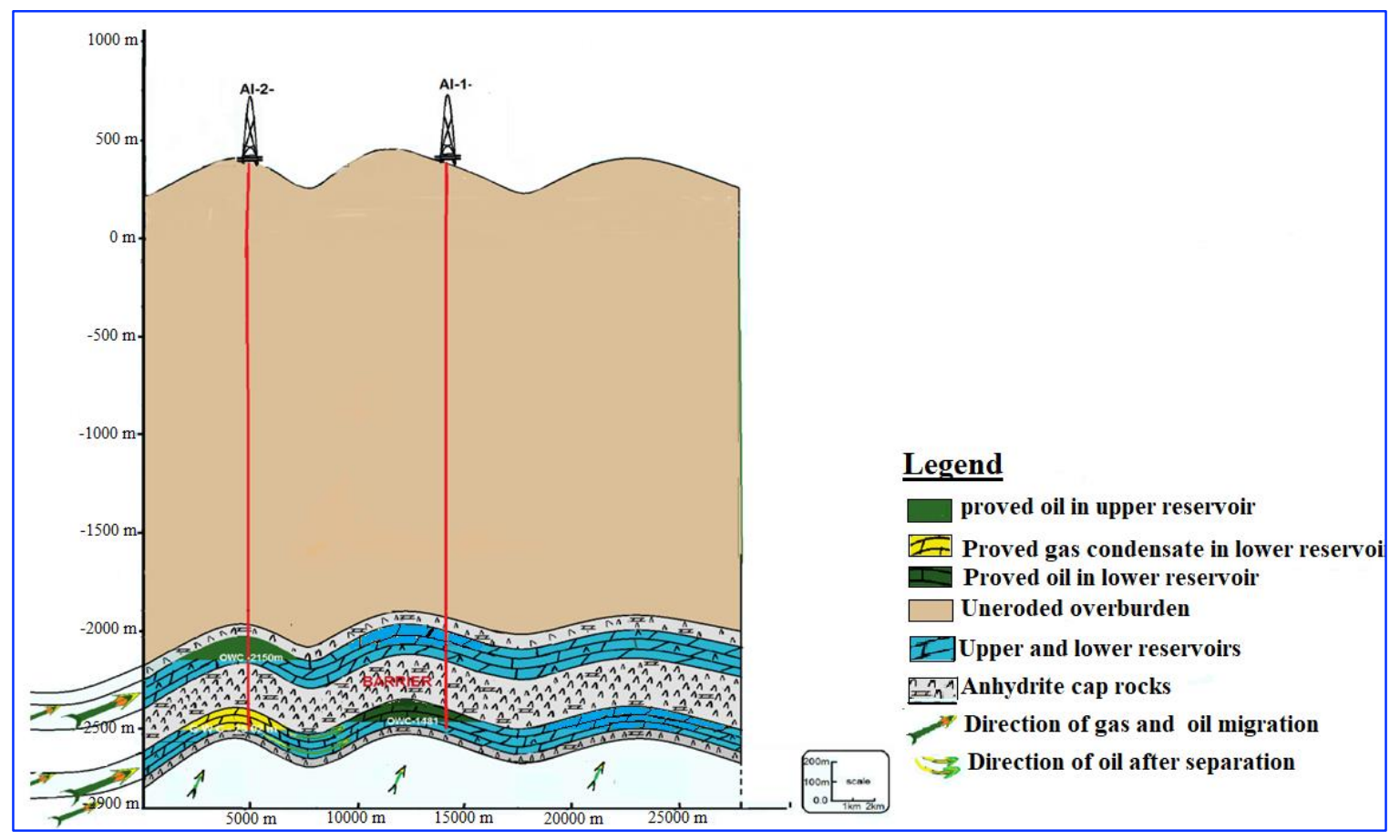

Fig. 3. Cross section in the Alan field shows two reservoirs and three domes 


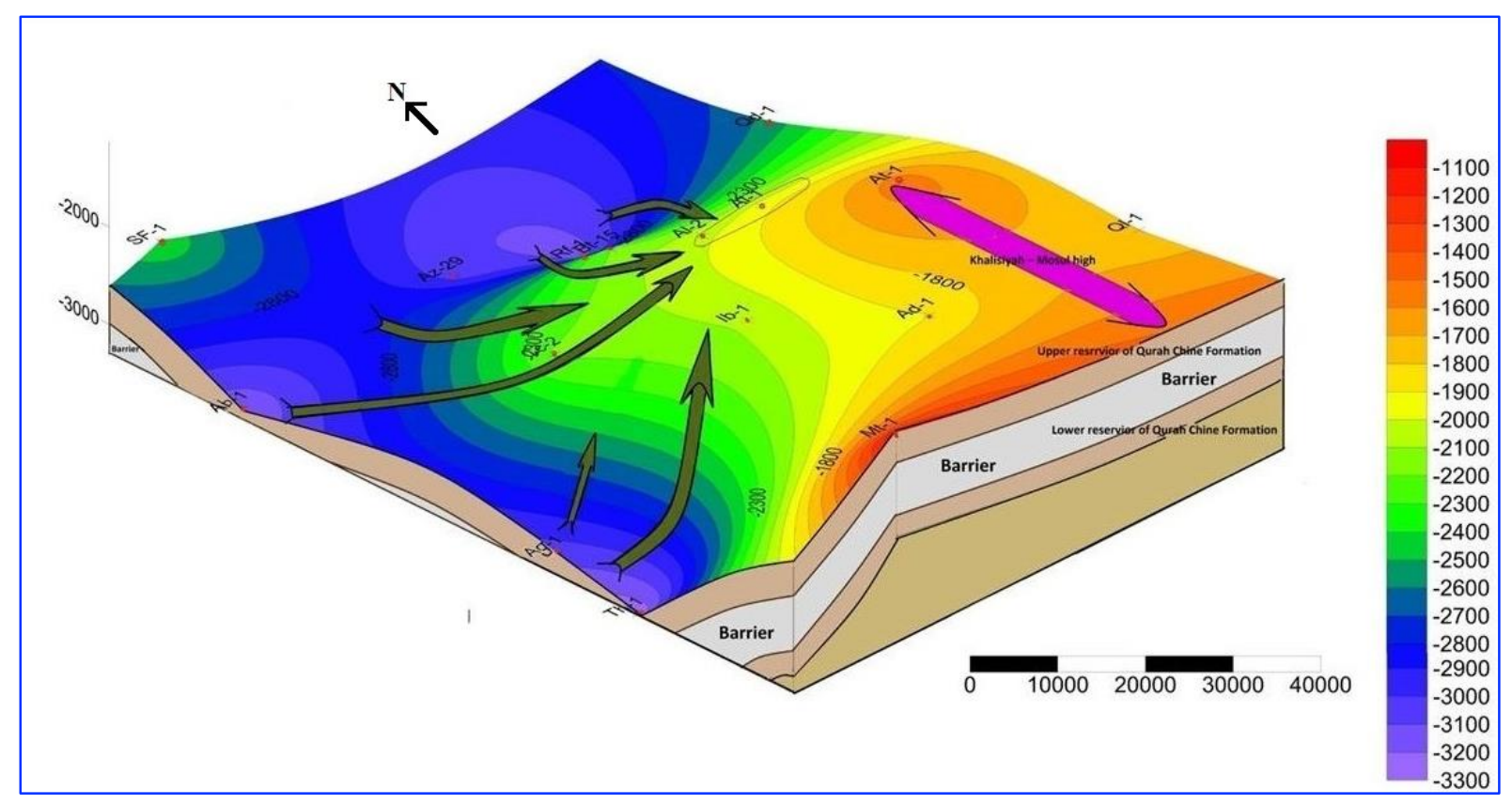

Fig. 4. Synoptic block diagram, panoramic view and reconstruction of architectural geometry of the Kurra Chine Formation, extracted from well data of northwest Iraq (see the text for name abbreviations of wells)

Table 1. Thickness variations in sequence of $U$. Triassic and L. Jurassic between wells Alan-1 and Alan-2, data from (N.O.C., 2015)

\begin{tabular}{|c|c|c|c|}
\hline Rock units & Thic. in Alan-1 (m) & Thic. in Alan-2 (m) & Difference in Thic. (m) \\
\hline L. Jurassic & 87 & 152 & 65 \\
\hline Evaporates of upper cap rocks & 137 & 84 & 53 \\
\hline Carbonates of upper reservoir & 125 & 116 & 94.5 \\
\hline Evaporates of lower cap rocks & 212.5 & 247 & \\
\hline Carbonates of lower reservoir & 171 & Not reach to lower contact & \\
\hline
\end{tabular}

\section{DISCUSSION}

There are some variations in the physical properties of the oil between the upper and lower reservoirs such as API gravity which is 31 API and 29.6 API for the upper and lower reservoirs, respectively (O.E.C., 2010) and there is an abnormal distribution of hydrocarbons, oil in the upper part of The Kurra Chine Formation and gas, the lighter, in the lower part of the formation in well Alan-2. The variety of the oil properties and abnormal distribution reflect difference in the thermal maturation, burial history, source rocks and structural evolution (Dahlberg, 1982 and 1995 and Fustic et al., 2012). Organic matters in the Kurra China Formation are type II and III kerogen in northwestern and northern Iraq (Al-Ameri, et 
al., 2009 and Edilbi, et al., 2019) and the formation is characterized by extensive fractures in the northern Iraq that it can be considered as reservoir a (Awdal et al., 2016). Kurra China Formation is source rocks in addition to reservoir rocks in some parts which is characterized by fracture. These source rocks enter the maturity stage due to the high thickness of the sequence from the Kurra Chine Formation upward (Fig. 3).

For the upper reservoir; charged oils have been migrated up-ward toward Alan Field that feeds the upper reservoir of western dome because it is the nearest (Figs. 3 and 4) in addition to the oil may be related to the Lower Jurassic source rocks that accumulate in the fractured reservoir rocks of the Kurra China Formation by the faults with high network fractures. Some Factors may limit the oil in the upper reservoir only in the western dome; the source rocks of hydrocarbon in the upper reservoir separate from the lower, thickness of the upper reservoir carbonate is little in comparison with the lower (Table 1), porosity of the upper reservoir is reduced due to the anhydritization processes that form anhydritizated doloston, and the last factor is the $220 \mathrm{~m}$ anhydrite barrier rocks between the upper and lower reservoirs prevent the hydrocarbone comes from lower source rocks.

For the lower reservoir; shale, marl and argillaceous limestone in the Mirga Mir Formation (Lower Triassic) and the bivalve-rich beds in the Beduh Formation (Lower Triassic) may have source rocks potential (Aqrawi et al., 2010) as well as the lower part of the Kurra Chine Formation as mentioned above enter thermal maturation and feed the lower reservoir by up-dip lateral migration toward Alan field. Gas condensate fills completely lower reservoir in the western dome, the nearest and lowest (Figs. 3 and 4). Gas oil contact reaches to spill point in western dome, and then push the oil to fill the middle dome, higher and away from the western dome. There are two scenarios of differential entrapment in the lower reservoir, the first one depends on Gussow's principle (Gussow, 1954) and the concept of fill and spill (Fustic et al., 2012) in which specific structurally setting plays the major role. Source rocks enter oil maturity window then feed and fill the closest structure, western dome, after displaces water then the source rocks enter gas window. Charged gas pushes the pre-existing oil from western dome to neighboring structure, middle dome, further away from source rocks. Lower seal of carrier bed in this model is close to the fluid contacts and spill points levels that affect the entrapment mechanism (Fig. 5) but in Alan field case no lower seal close to fluid contacts and spill points. The second scenario is in which generation of hydrocarbon is before the formation of Alan anticline; Alan area subjects into two stages of tectonic uplift, the first one is development of the Mosul High from Late Cretaceous to Late Oligocene (AlAzzawi, 2013 and Burberry, 2015). 


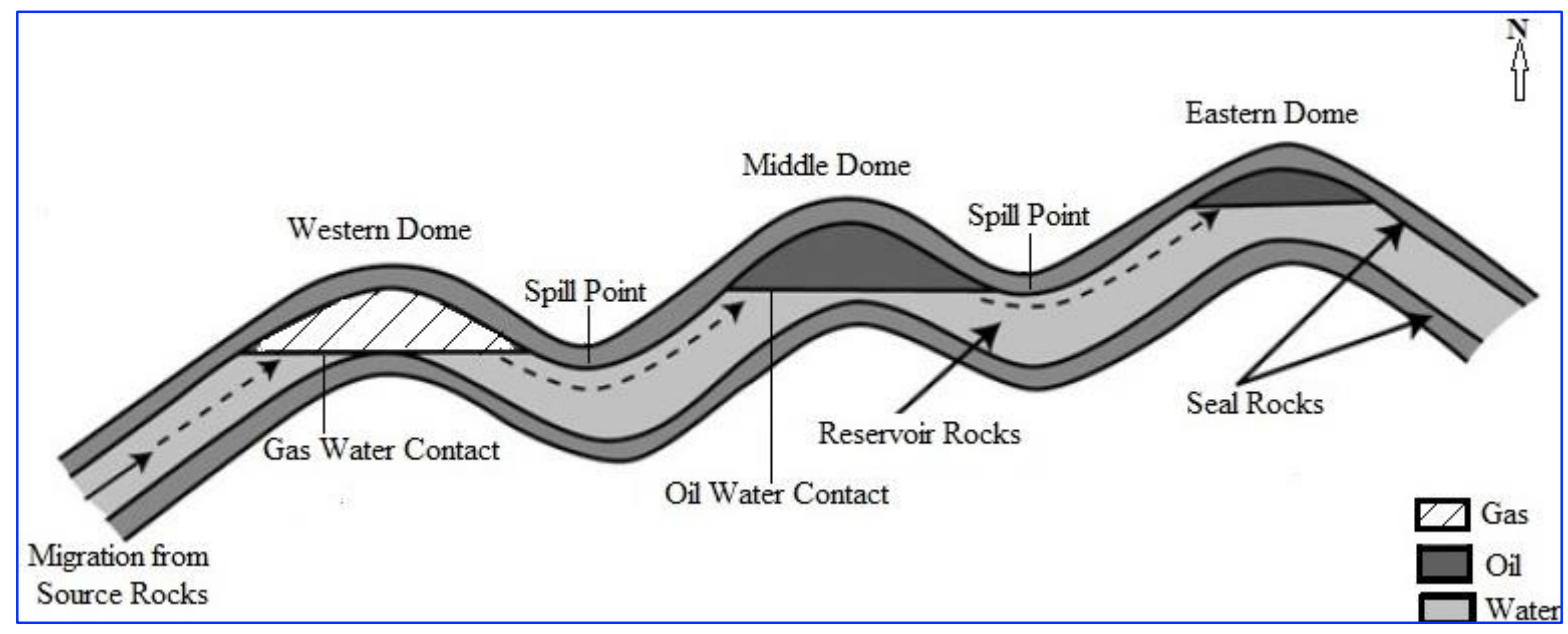

Fig. 5. Differential entrapment of hydrocarbons in the lower reservoir of Alan field depend on Gussow's principle of differential hydrocarbon entrapment (Gussow, 1954) and concept of fill and spill (Fustic et al., 1012)

The second stage of tectonic uplift is the Alpine folding in foreland anticlines north and northeast Iraq. The folding is paroxysmal not progressive at the end of Pliocene (Numan and Al-Azzawi, 2002, Jassim, 2019 and Alkhatony et al., 2019). During the first tectonic stage the source rocks were entered maturity levels before the development of Mosul High due to the thickness of the sequence from source rocks upward to the Late Cretaceous is about $2151 \mathrm{~m}$ in well Alan-1 with Upper Jurassic gap and some unconformities that sufficient to allow the source rocks to generate hydrocarbons with considering the source rock is deeper in the northwestern Iraq more than 1200 m (Fig. 4). The hydrocarbons migrate laterally toward Mosul High due to up-dip movement.

The second stage of upliting allows the fluids to continue lateral migration toward Alan anticline, the lighter fluid, gas, reaches first to the lower resevoir of the Kurra Chine Formation in the western dome but prevented to reach upper reservoir due to the anhydrite unit between the two reservoirs. While the gas fills the western dome and the gas - oil contact reaches to spill point the oil continued to lateral migrate and fill the middle dome therefore, oil or water is in the eastern dome. The entrapment of hydrocarbon in the lower reservoir of the Kurra Chine Formation was controlled by structural setting (folding). (N.O.C., 2015) suggests that the variation in the fluid contact levels between western and middle domes is due to normal fault between the two domes that makes contrast in elevation of rock masses. Another factor plays an important role to distribute the hydrocarbone in lower reservoir is increasing the voids of porosity and fratures after eroded about $800 \mathrm{~m}$ of overburden, where the sequence from Middle Miocene upwaed that include Fatha, Injana and Muqdadia formations. The increasing of void due to unloading allows the gas to saperate from the oil 
that fills lower reservoir in the western dome and push the oil to the middle. Carbonate of lower reservoir behaves elastic material. The elasticity of carbonates is high in compersion with other rocks (Van der Pluijm and Marshak, 2004)

\section{CONCLUSIONS}

The current study shows some important results, which are given conclusions as in the following:

1. There are two reservoirs in the Alan oilfield, upper and lower. Both reservoirs are within the Kurra Chine Formation. They are in the upper and lower parts of the formation respectively that separated by $\sim 220 \mathrm{~m}$ of anhydrite cap rocks.

2. The Alan field locates in the northwest margin of the Mosul high. The Kurra Chine Formation of Alan Field rises about $1200 \mathrm{~m}$ than the northwest Kurra Chine sedimentary basin. The source rocks of the deepest part of basin in the northwest Iraq enter thermal maturity and generates hydrocarbon that migrates laterally toward the Alan field.

3. Tectonics, structural and stratigraphic situations play important role of differential entrapment of hydrocarbons in the Alan field. There are two stages of tectonics that develop Alan Field, the first one is uplifting of Mosul high where the field is located in the northwesterm margin of the high. The second tectonic stage is compressive stress of Alpine orogeny.

4. The difference in elevation between gas-water contact in the lower reservoir of the western dome and oil-water contact in the middle dome is due to the structural factor, folding, and elastic behavior of carbonates.

5. Oil of the upper reservoir was generated due to the source rocks of the upper part of the Kurra Chine Formation and may be related to the Lower Jurassic source rocks and the faults with high network fractures helped to accumulate in the fractured reservoir rocks of the Kurra China Formation.

6. The possibility of oil existence in the lower reservoir of eastern dome is high due to the water-oil contact is with the spill point between the middle and eastern domes.

\section{REFERENCES}

Al-Ameri, Q. H., Al-Dlaimy, A. J., and Al-Khafaji, A., 2009. Palynofacies and hydrocarbon generation potential of the upper Triassic Kurra Chine Formation and lower part of the Baluti Formation, Mosul block, Northwestern Iraq, Arabian Journal Geoscience, 273-283.

Al-Azzawi, N. K., 2013. Paleo and New- Tectonics of the Mosul fault and its Impact on the Tectonics of the Foreland Area of Iraq. Iraqi National Journal of Earth Science, 13 (1): 59-74. 
Aqrawi, A. A. M., Goff J. C., Horburu, A. D., and Sadooni, F. N., 2010. The Petroleum Geology of Iraq. Printed in Great Brittain by Cambrian Printers, Aberystwyt.

Awdal, A., Healy, d., and Alsop, G. I., 2016. Fracture patterns and petrophysical properties of carbonates undergoing regional folding: a case study from Kurdistan, N Iraq, Marine Petroleum Geology, 71: 149167.

Bellen, R. C. V., Dunnington, H. V., Wetzel, R., and Morton, D. M., 1959. Lexique Stratigraphic International Asia. Fascicula 10a. Iraq.

Buday, T., 1980. The Regional Geology of Iraq. Vol. 1. Stratigraphic and Paleogeography. Puplications of GEOSURV. Baghdad. 445p.

Burberry, C. M., 2015. The effect of basement fault reactivation on the Triassic-recent geology of Kurdistan, North of Iraq. Journal of petroleum geology, 38:37-58.

CGG, 1974. Aeromagnetometric and aerospectrometric survey of Iraq. Massy, France, GEOSURV int. rep. no. 2642.

Dahlberg, E. C. 1982. Applied Hydrodynamics in Petroleum Exploration. New Yourk: Springer Verlag.

Dahlber, E. C. 1995. Applied Hydrodynamics in Petroleum Exploration. Second Edition. New Yourk: Springer Verlag.

Edilbi, A. N., Kolo K., Muhammed, N. R., Yasin, S. R., Mamaseni, W. J., and Akram, R., 2019. Source rock evaluation of shale interval of Kurra Chine Formation, Kurdistan Region-Iraq: An organic geochemical and basin modeling approach. Egyptian Journal of Petroleum, 8: 315-31.

Fouad, S. F. A. 2015. Tectonic Map of Iraq Scale 1: 1000 000, third edition. Iraqi Bulletin of Geology and Mining, 11(1): 1-7.

Fustic, M., Bennett, B., Huang, H., and Larter, S., 2012. Differential entrapment of charge oil-new insights on McMurray Formation oil trapping mechanisms. Marin and Petroleum Geology, 36: 50-69.

Gussow, W. S., 1954. Differential entrapment of oil and gas - fundamental principles. American Association of Petroleum Geologists, 38: 816 - 853.

Hall, P. K., 1958. Geological Map Kurdistan Reconnaissance Series Scale 1:100 000 Sheet K2 Amadiya Manuscript report, GEOSURV, Baghdad.

Jassim, S. Z., Karim, S. A., Basi, M., Al-Mubarak, M. A., and Munir, J., 1984. Final report on the regional geological survey of Iraq. Vol. 3. Stratigraphy. internal report. Geological Survey of Iraq.

Jassim, S. Z., and Goff, J. C., 2006. Geology of Iraq. First edition. Printed in the Czech Repuplic.

Jassim, S. Z., 2019. Tectonic Units of the Arabian Plate Boundary, PowerPoint presentation, Baghdad University.

North Oil Company (N.O.C), 2015. Update the Structural map of Kurra Chine Reflector using seismic data.

Numan, N. M. S., 1997. A plate tectonic scenario for the Phanerozoic succession in Iraq. Iraqi Geological Journal, 30 (2): 85-119.

Numan, N. M. S., and Al-Azzawi, N. K., 2002. Progressive versus paroysmal Alpine folding in Sinjar anticline Northwestern Iraq. Iraqi Journal of Earth Science, 2 (2): 59-69.

Oil Exploration Company (O.E.C), 2009. Interpretation of Seismic Data of Kurra Chine Reflector in Alan Field.

Oil Exploration Company (O.E.C), 2010. Geological and Evaluation study of Kurra Chine Formatrion in Alan field.

Sadooni, F. N., 1995. Petroleum prospects of upper Triassic carbonates in Northern Iraq, Journal Petroleum Geology, 18:171-190.

Van der Pluijm, B. A., and Marshak, S., 2004. Earth Structure. An Introduction to Structural Geology and Tectonics. Second edition. $641 \mathrm{p}$. 